\title{
THE INDIAN ELECTION OF 1951: FIRST TEST AS A NEW INDEPENDENT DEMOCRATIC STATE
}

\author{
Nadia Abdulkadhim Salman Al-Shammari \\ Azharudin Mohamed Dali
}

\begin{abstract}
This article explores how the Indian General Election of 1951, the maiden general election of independent India, was held with much expectations amidst mingling hope and fears. The vital concerns were the geographic spread of the constituencies and the populations that were divided along caste, faith and belief lines. On the other hand, positive signs were the active participation of political parties and the availability of the Constitution as the guiding principle, as well as a well-structured election commission. The elections paved the way for the sensitization of minority groups and the numerous linguistic groups, thereby reshaping not only the individual states but also the country as a whole towards becoming a democratic country. The election's immediate outcome was the emergence of state parties and national parties. This article explores how the first Indian Election of 1951 influenced Indian democracy and politics.
\end{abstract}

\section{Introduction:}

The British left in India a well-structured administrative infrastructure, which set the stage for the general election in 1951. The Indian Constitution's essential provisions as regards elections were specified under Part XV (Articles 324-9) of the Indian Constitution of 1950. According to Article 326, "The elections to the House of the People and to the Legislative Assembly of every state shall be on the basis of adult suffrage". This Article embodied the basic character of the Indian electoral system, described by the Electoral Commission as an "act of faith". Some predicted any election was doomed to failure, citing the heavily institutionalised social composition would not guarantee that all citizens over the age of 21 were given equal opportunity in the electoral process. Nevertheless, this historic decision did a lot to shape the nature of the electoral system in the democratic political system of India. ${ }^{1}$

The Constitution provided for the size of the Lok Sabha and the various state assemblies and constituencies. Hence, the Delimitation Commission Act of 1952 was passed. For the purposes of election, the states were divided into territorial constituencies in such manner that the ratio between the population of each constituency and the number of seats allotted, so far as practicable, were the same throughout the state. The allocation of Lok Sabha seats to the States (as well as the Assembly seats) and the division of each State into territorial constituencies were readjusted after every census. Under the Delimitation Commission Act of 1952, Lok Sabha seats were allocated to the states and a fixed number of seats in the State Legislative Assemblies was established. In every case, one parliamentary constituency was constituted by a combination of Assembly Constituencies. ${ }^{2}$

W.H. Morris Jones, writing on 28 June 1952, few months after the first Indian general elections, mentioned the following:

No easier was the delimitation of constituencies, also completed during 1951. The Constitution had lain down that each member of the House of the People should represent between 500,000 and 750,000 electors. The Commission received proposals from each State and carried out the job of delimitation in consultation with Advisory Committees for each State 
appointed by the Speaker and composed of members of the central legislature from those States. ${ }^{3}$

The Electoral Commission had to be pragmatic in the delimitation of constituencies. Wherever necessary, they maintained existing administrative local structures in the States and apportioned seats among districts in proportion to the size of their population. Jones further reported that:

Proposal that area should also be considered, so that sparsely populated parts would receive a weighted representation, was rejected. Singlemember constituencies are the rule but a number of double-member constituencies had to be created in order to allow one reserved seat for the evenly distributed scheduled castes. (The scheduled tribes, geographically more concentrated, could be catered for by reserved single member constituencies). Since the number of seats in a State Legislative Assembly is a multiple of the number of seats belonging to that State in the House of the People, several Legislative Assembly constituencies (each representing at least 75,000 voters) are combined to make a single constituency for the House of the People. ${ }^{4}$

In order to prepare for the elections, Article 325 of the Indian Constitution mandated the Election Commission to prepare Electoral Rolls. This Article had it that:

"There shall be one electoral roll for every territorial constituency for election to either House of Parliament or to the House of the Legislature of a State and no person shall be ineligible for inclusion in any such roll or claim to be included in any special roll for any such constituency on grounds of religion, race, caste, sex, or any of them." Unlike some advanced democratic countries, the responsibility for registering voters was not an individual responsibility but rather public duty of the Government, which makes it an enormous task for the Election Commission. The scale of this task of registration would be appreciated when put into proper perspective. For the first general election of 195152, more than 173 million eligible voters had to be registered by the Electoral Commission employing mainly house-to-house canvas across the entire length and breadth of the country. Hence large number of electoral staff had to be recruited and trained to take charge of this largescale operation of the election to ensure accuracy of registers; and that bogus voters were not registered through checking and rechecking. ${ }^{5}$

\section{Ground Realities and Challenges}

Some challenges were encountered as numerators were not sufficiently qualified to carry out the tasks. This situation was aggravated by widespread illiteracy and language and dialect barriers. Describing some of the measures put in place by the Electoral Commission to address some of these challenges, Jones wrote:

The enfranchisement of an illiterate people required a number of special measures. Parties had, for example, to be distinguished by means of pictorial symbols. At a conference held by the Commissioner in July 1951, a range of symbols was discussed and the parties expressed their 
preferences, the final allocation being made by the Commissioner. Fourteen symbols were allotted to the all-India parties, while eleven more were made available for different local State parties. In order to avoid asking the voter to make any mark on paper, each party had to have a ballot box marked with its symbol, so that the voter had simply to drop the paper in the box of his choice. Since each voter was choosing a representative for the State Legislative Assembly, he had to repeat the process; each polling booth contained separate enclosures for the two acts of voting, each equipped with a set of ballot boxes. In many polling stations women were provided with separate booths staffed by women assistants. About three million boxes had to be made. ${ }^{6}$

Moreover, large number of women failed to register themselves as they refused to give their full names for fear of betraying their husbands (who culturally were the only people who had the right to know their full names). It was reported that some 2.8 million women did not give their full proper names to the registrars, and therefore could not be included in the electoral roll. There were special problems including linguistic complications, the difficulty of obtaining accurate names in a country where many people were known by the same designation, the ambiguous status of hundreds of thousands of refugees from Pakistan, and the impossibility of obtaining reliable information in 'backward' areas.

Upon completion of the Electoral rolls, the Constitution required the President of the Union to issue notification to the electorates to vote in their Lok Sabha for representatives at the union level. The governors of the states issued similar notification to the electorate to vote in their representative to State Legislative Assemblies. Following such notifications, the Electoral Commission issued notification specifying the time table for nominations, scrutiny, withdrawals, and polling. All candidates were expected to meet the requirements according to the Constitution and the Representation of People Act of 1950 and 1951. Candidates were fielded by recognised political parties or could stand as independent candidates. There was no requirement for a local residency in the constituency. The electoral law only required that the candidates must be a registered voter in any constituency or the other of the legislatures to which he/she was seeking election. Candidates were required to pay a deposit prior to filing in a nomination paper, and each candidate was liable to forfeit if he/she failed to poll more than one-sixth of the votes the total number of votes valid votes cast in his/her constituency. The deposit for the Lok Sabha doubled that of the Legislative Assembly whilst the deposit for the candidates of Legislative Assemblies varied from state to state. The nomination papers were scrutinised by returning Officers upon closure of nomination and a final list of valid nominations was drawn up was drawn about three weeks before the elections, marked by electioneering campaigns by political parties and independent candidates. The final preparations for elections were supervised by the Chief Election Commissioner and the Chief Electoral Officer. ${ }^{7}$

The selection of candidates, which was a major aspect of the electoral process for the General Elections of 1951, was done mainly through the instrument of political parties. Ramasharay Roy $^{8}$ observes that "among all the procedures that make up the final electoral process.... the selection of candidates is by far the most important". ${ }^{9}$ Jones highlights the significance of selection in Indian electoral process vis-à-vis the role of political parties as thus:

To underline the central significance of candidates' selection for the internal health of the party is not of course to imply that this is its only importance. From the point of view of the party as a contestant against 
other parties, the decision as to candidates may make the difference between victory and defeat, and it should be a matter of nice calculation to assess which applicant for a ticket has the resources- of personality, energy, finance, and, above all, connections or influence-which will win the day. From the point of view of party as combatant in the arena of the representative assembly, candidate selection determines the quality of the forces available for battle in the public forum. Again, this process has to be seen as the one which determines the quality of the reservoir from which talent will be filtered through Government level. Finally, from the standpoint of the individual applicants, here is a critical moment in the shaping of a political career. ${ }^{10}$

The aforementioned observation indicates the tremendous bearing selection process had on the "quality of leadership" and the "fortunes of political parties". Similarly, it also shows the impact of the individual on the "nature of the electoral process, and on the character of the leadership and orientation of the political system". ${ }^{11}$ There was no uniform process of selection for political parties to follow during the candidate selection process of the 1951 elections. For instance, Jawaharlal Nehru, the Prime Minister of India, impressed his Congress Party to bring forward capable candidates. The task was assigned to the District Congress Committees and the Pradesh Congress Committees. Nevertheless, individual Congress political leaders both at the Union and state levels often played crucial role in the candidate selection process. These leaders included the Chief Ministers, the state-level Presidents of the Pradesh Congress Committees, special observers from the central election committees, working committees, and the Prime Ministers. ${ }^{12}$

\section{Electioneering Campaign}

Following the candidate selection process for the 1951 General Elections, political campaigning, debates and dissemination of information commenced to arouse the interest of voters regarding pertinent national issues. There was a statutory period of three weeks dedicated to political campaigning which was closed 48 hours before polling day, when all electioneering and campaigning were legally stopped. ${ }^{13}$ The political campaigning process promoted the mobilisation of voters and their politicisation and integration into the new democratic political system. The political campaign also generated spectacular scenes akin to their national festival or tanasha, which had far-reaching impact on the remotest of the villages on the governmental power in New Delhi; thereby exposing an average Indian to the various political messages of general election.

Political campaigning took various forms depending on the communal setting, whether it was in the village or in the city. The campaign in the village involved candidates conducting rallies using jeeps, bullock carts, and even by foot. The activities in the cities involved neighbourhood street corner meetings, house-to-house canvassing by party agents, often with the candidate paraded on a jeep waving at crowds through town. During these activities slogans and political messages were conveyed. ${ }^{14}$ According to Brass, there were three means of communicating political messages: through printed manifestoes, political speeches, and private and implicit appeals. Political Parties developed election manifestos, which provided platform for parties and individuals to show various issues and plans to address them and allowed voters to compare parties and candidates. It has been noted that "what manifestos do provide is a perspective on some of the major public policy issues for the country at the time of the election, as perceived by those political party elites involved in drafting these documents". ${ }^{15}$ Party slogans allowed parties to pass their messages across to 
the electorate. Political party manifestos were printed out in English and in vernacular languages bearing the party platform and its distinct messages for the electorates.

For example, the National Congress, the then dominant political party of the Union of India States under the leadership of Nehru, included the topical issue of linguistic nationality principle in its manifesto for first general election of India in 1951. ${ }^{16}$ "As a nationalist political party, the Congress showed their support to the reorganisation of Indian states on a linguistic basis and based upon the consent of the people of the concerned states. The Congress tried to gain political capital from the masses out of such a sensitive issue as they tried to show the party's relevance to the interest of the ordinary people across the federation. Similarly, the Socialist Party also used the linguistic nationality principle as a platform in their manifesto for the 1951 election to win the support of the concerned electorates. The Socialist Party was "in favour of the redistribution of States on linguistic basis consistently with geographical contiguity and economic viability."17 The notion of political parties identifying themselves with a key federation-wide problem appeared was a smart political move, considering the newly independent Indian nation-state was grappling with the effects of British colonial administration. The latter, in retrospect, was insensitive to 'linguistic nationalities' in its administrative organisation and structures.

Moreover, candidates made political speeches at city centres or village squares expressing their political messages and platforms. Signifying a departure from the earlier approach of party-printed manifestoes and political speeches, private and implicit approach through informal meetings were an effective strategy for community engagement; linking the candidate with the people. This also gave opportunity for rival candidates to capitalise upon the perceived weaknesses (corrupt practices, criminal activities, moral issues, among others) of the opposing candidate with the intention to gain political capital out of it. ${ }^{18}$

Several factors have been identified to have influenced the voting behaviour of the Indian electorate during elections. These include appeals to class, community, caste, and faction loyalty as well as personal attractions towards popular and charismatic leaders. At the local level around countryside, the most important factor was caste solidarity. Large and influential castes in a constituency tended to back either a respected member of their caste or a political party with whom their caste members were identified with. ${ }^{19}$

\section{Commencement of Voting}

The process of voting in the first general election of India was an exciting exercise for the electorates in the midst of growing nationalism and pertinent national developments. India adopted the adult suffrage for the first time in the 1950 and 51 Elections. K.M Panikkar, ${ }^{20}$ a key member of States Reorganisation Committee reported an eye-witness account of this fascinating spectacle as follows:

The electorate numbered over 180 million-that is, as much as the total combined population of the United Kingdom, France, Federal Germany, Belgium, Holland, and the Scandinavian states. Over 100 million voters exercised their right to franchise; over 10, 000 candidates contested the elections and over three thousand were elected to man the new democratic institutions that the constitution had set up. Four major political parties took part in the election: The Congress, the Praja, Socialists, the Communists. ${ }^{21}$ and the Hindu Mahasabha. It was the greatest experience in democratic elections conducted openly in the full view of observers from many countries. All the leading public personalities toured the country in the weeks preceding the election and the issues were clearly stated. ${ }^{22}$ 
India followed the British Parliamentary democracy model in that the election for members of the Lok Sabha must be held within five years of the life span of the previous parliament. The election to the State Assemblies was simultaneously conducted through similar schedule of polling with that of the Lok Sabha. Nevertheless, the President could call for a general election upon the advice of the Prime Minister any time sooner during the life span of a particular parliament. ${ }^{23}$ The first General Election was conducted over the period of several weeks beginning from 25 October 1951 to 21 February 1952. Most of the voting was conducted in January 1952 with the participation of the following major political parties: The Indian National Congress, the Socialist Party, the Communist Party, the Kisan Mazdoor Praja Party, and Bharatiya Jan Sangh party. The Election Commission had the mandate to decide which parties would be recognised as national parties and state parties. Although the Congress had consistently proven to be the dominant national party, several parties also took part in the first general election.

At the time of independence, the major active political parties were the Indian National Congress, the Socialist Party, the Communist Party, the Kisan Mazdoor Praja Party, and the Bharatiya Jan Sangh party. All these parties were national or all-India in character, structure, and policies. The all-India political parties conducted their own congresses or conventions and developed their own manifestos for the purpose of contesting general election across the Indian Union. They were recognized by the Electoral Commission for the purpose of the first General Election of $1951-52 .{ }^{24}$ It is important to point out that most of these parties included in their manifestos hotly debated national issues and programmes including the linguistic nationality principle of state reorganization, and other social, economic, and political issues. ${ }^{25}$

No fewer than 77 so-called political parties took part in the first General Elections in 1951-2. Of these 14 were reorganised by the Election Commission as national parties, and fifty-nine were recognised as State parties. Of the 51 parties which put up candidates for the Lok Sabha (then known as the House of the People), only 20 won one or more seats and only four won nine or more seats. In fact, the largest number of opposition seats was won by the Communist Part of India, although it received only 16 seats whereas the ruling Congress Party had $364 .{ }^{26}$ The total number of registered voters was 173,213635 out of which a total of $171,747,300$ electors voted in the contested elections. The results of the major national parties were as follow:

\begin{tabular}{|c|c|}
\hline Political Party & Vote Percentage \\
\hline The Indian Congress Party & $45 \%$ \\
\hline Socialist party & $11 \%$ \\
\hline Kisan Mazdoor Praja Party (KMPP) & $6 \%$ \\
\hline Communist party & $4 \%$ \\
\hline Jan sangh & $3 \%$ \\
\hline Other parties and independent candidates & $31 \%$ \\
\hline
\end{tabular}

The Indian Congress Party gained $45 \%$ per cent of the votes; Socialist registered $11 \%$, Kisan Mazdoor Praja Party (KMPP) 6\%, Communist $4 \%$, Jan sangh 3\%, other parties and independent candidates accounted for $31 \% .{ }^{27}$ The Congress won $45 \%$ of all the total votes cast -74.43 per cent of the seats compared to the Socialist party, which secured 11 per cent of the votes and obtained 2.4 per cent of seats. ${ }^{28}$ 
The 1951-1952 elections ushered in an era of institutionalized and fair elections for many succeeding years in India. After the 1951 elections, the Election Commission established a rule that only those political party that have polled at least $3 \%$ of total valid votes cast in previous election were considered as national parties. This rule was applied in 1957, thereby reducing the number of recognised parties to four in the second and third general elections and five in the fourth general election. It was also reported that the First General election of 1951-52 contributed towards the "collapse of the Communist rebellion in Telangana". ${ }^{29}$ The inclusivity of Indian political movements exposed the greater majority of the Indian society to a form of sustained politicization, which made the populace less amenable to accepting communist slogans.

The Indian government under the Nehru-led Indian National Congress launched the First Five Year plan in late 1952. ${ }^{30}$ It should be noted that this plan embodied the economicplanning concept that the Congress promised in their manifesto and which it proposed to the electorates during the election campaign for the first general election. The First Five Plan adopted a socialist touch with the aim of creating a broad-based appeal among the common people. The party adopted the following resolution at the Congress session of Avadi in January 1955:

In order to realize the object of the Congress and the Constitution and to further the objectives stated in the Preamble and the Directive Principles of the State Policy of the Constitution of India, planning should take place with a view to the establishment of socialistic pattern of society where the principal means of production are under social ownership or control, production is progressively speeded up, and there is equitable distribution of national wealth. ${ }^{31}$

The Congress followed through this idea in the Second Five Year Plan, which was implemented from 1956-61, quite in time for the second general election of 1957. The economy of the Indian union witnessed a boost "on account of the post-Korean inflationary boom and of the enhancement of import and export duties during 1950-51. Customs revenue leapt from 157.2 scores in 1950-51 to 232.00 scores in 1951-52". ${ }^{32}$ Within this picture, the first Five Year Plan focused on agriculture, particularly food production, as a key area of policy intervention by allocating one-third of the total expenditure of $£ 1,800$ million. They aimed to scale up food production which was 54 million tons per year by additional 7.6 million. By 1954, under the First plan, food production went up to 68 million tons, and averted "the danger of mass starvation." 33

However, economic imbalances and unequal economic development was still miring regional States. This often created demand for preference for "son of the soil" over "outsiders" in case of opportunities for such as employment and education activities. ${ }^{34}$ Krishnaswami observes such inequalities among the states and between States and the Union at the centre were not only limited to economic sphere but also the political sphere. Having extra-territorial powers over the regional states, the centre could "intervene at will and oust provincial authority", thus potentially threatening the Federation itself. ${ }^{35}$

Being aware of the problem of inequality, the Congress-led Government sought to promote regional development by addressing the issue of regional imbalances. For instance, the key objective of the 1956 Industrial Policy Resolution of the Government was to secure "a balanced and coordinated development of the industrial and agricultural economy in each region [so that] the entire country [could] attain higher standard of living." 36 The Second Five Year Plan, subsequently, was also designed to target regional economic imbalances. 
The Official Language Commission was established in 1955 to conduct the first review of the language issue. The Commission comprised 20 members that represented all major languages of the Indian Union. The Commission looked at the implications of the usage of Hindi language, the implication of using regional languages or mother tongue as medium of instruction in the education system, and that Hindi should be introduced as a subject at secondary level. At university level the commission decided that the choice between Hindi and regional languages should be left at the discretion of the universities. The Commission observed that the use of Hindi at Union level administration depended on the preparation of standard terminology and training of staff, in which case Hindi language test was to be conducted for existing staff and new entrants. The language of legislation and of the Court was to remain in English pending preparatory work for change-over to an authentic standardised Hindi script version. ${ }^{37}$

The linguistic reorganization of the States was another post-election activity that the government embarked upon to fulfil its pledges in the past election. There was now a strong urge for a re-organisation of state along linguistic lines. Following independence in 1947, there was already a clamouring for the re-distribution of states along linguistic lines. The Indian National Congress, a forbearer of Indian nationalism, gradually shifted its position from an initial disapproval to accepting the reality of the linguistic sentiments especially since the end of the First World War in 1919. Hence various committees - for example, the All-party congress, Dar Commission, The Nehru Committee - were tasked to investigate the issue at various stages until the setting up of the States Reorganisation Commission in 1953. The commission examined the structure of the Indian States (into Parts A,B,C, \& D) as adopted in the Constitution of 1951 by the Constituent assembly; thus paving the way for passing in 1956 of the States Reorganisation Act, which created fourteen Indian regional states and six centrally administered states. ${ }^{38}$

Since the late nineteenth century, when Indian nationalism was on the rise, Indian states generally focused on attaining independence from British colonial administration. They were united for that purpose, although there were instances when some States demanded for an arrangement according to linguistic characterization, which was downplayed by the British in favour of administrative convenience. Nevertheless, with the partition of Pakistan from the Indian Union, and the independence of India in 1947, sentiments for linguistic reorganization of Indian States gathered across the Indian Union. Whilst recognizing 14 national languages in the Eight Schedule of the 1951 Constitution, the Constituent Assembly did not specifically address the question of linguistic re-organisation of States. Prior to the 1951 election, with violent agitation and demand from States such as Andhra Pradesh, the issues occupied centre stage as political parties took. All these led to the creation of States Reorganisation Commission. ${ }^{39}$

Nevertheless, it is important to point out that the Constituent Assembly did tackle the issue of language policy in the Constitution (Part XVII), which however became a political concern as it evaded the term 'national language', and designated Hindi Devanagari script as 'the official language'. The constitution stipulated that English could be used for fifteen years from 1950 for official purpose alongside Hindi, which, on the other hand, had to be authorised by the President. It further stipulated a time frame for implementation and review by the Parliament. ${ }^{40}$

\section{Conclusion}

The first Indian election set the tradition for regular elections. It also established the character of the political parties, of being national or state. The outcome of the election set the national priorities for the winning parties. Thus, the Five Year Plans, Language Policy Bill, and decentralized policies accorded more space to states and for the voters to interact with their 
elected representatives. Regular elections also inculcated a mechanism to check and review election manifestos and claims made by leaders.

The first election succeeded in unfolding the diversity of Indian cultures. It was also evident that there was a number of different political parties promoting different ideologies. However, it became imperative for them to form alliances and collaborate with each other to form a government. The common agenda of all political parties was the national agenda. It is clear that from the development of the 1951 Indian Elections that allocation of resources played vital role in organizing the election. The majority of registered voters, including the women folks, successfully cast their votes. On the other hand, socialist parties appeared as a major political threat to the Congress party.

Overall, the election demonstrated that the vastness of the country, with dispersed populations, each divided along different faith lines, posed a herculean challenge for the contesting political parties.

\section{Notes}

1. W.H. Morris-Jones, Language and Region within the Indian Union, London: Institute of Commonwealth Studies University of London, 1967, pp. 108-109.

2. W. H. Morris Jones, "The Indian Elections". The Economic Weekly. June 28, 1952, pp. 235-249; Election Commission of India, "The Electoral System of India". http://www.doccentre.org/docsweb/Electoral-Reforms/Electoral-System-India.htm. Accessed 11 April 2017.

3. Norman D. Palmer, Elections and Political Development: The South Asian Experience, London: C. Hurst \& Company, 1975, p.109.

4. Ibid., pp.111-112.

5.See W. H. Morris Jones, “The Indian Elections”, pp. 235-249.

6.Ibid. p. 112.

7 Ibid., p. 113.

8. Professor Ramashray Roy is "an eminent political philosopher and prolific writer whose work has opened up new vistas in the study of development and democracy in India". He undertook his PhD at the University of California, Berkeley, in 1965. He had been a Senior Fellow and one of the founding members and later Director of the highly reputable Centre for the Study of Developing Societies (Delhi). Moreover, also served as the Director of the Indian Council of Social Science Research (New Delhi); and be became a Fellow for several institutions including the Indian Council of Historical Research (New Delhi), the Indian Institute of Advanced Study (Simla). ProfessorRamashray Roy has authored several books on elections, democracy, politics and society in India. Some of his works include: Democracy in India: Form and Substance (2005); Dialogues on Development: The Individual, Society and State and Political Order(1986); Grass-roots and National Perspectives (2007); SAGE Publishing: Available at ; Ramashray Roy and Ravi Ranjan, Essays on Modernism, Democracy and Well-being: A Gandhian Perspective, New Delhi: SAGE Publications India, 2016, p. 311. https://us.sagepub.com/en-us/nam/author/ramashray-roy. Accessed 11 April 2017. 9. Ibid., p. 115.

10. Ibid., p. 115-116

11. Ibid., p.116.

12. Ibid., pp.116-119.

13. Paul R. Brass, The New Cambridge History of India IV (1): The Politics of India Since Independence, London: Cambridge University Press, 1994, p. 97; see also, Norman D. Palmer, Elections and Political Development: The South Asian Experience, p. 139.

14.Ibid.

15. Norman D. Palmer, Elections and Political Development: The South Asian Experience, p.130.

16. Report of the States Re-Organisation Commission 1955, p.14.

17. Ibid., pp. 17-18. 
18. Paul R. Bass, The New Cambridge History of India, p.97.

19. Ibid., pp. 97-98.

20 K.M. Panikkar, was a member of the Constituent Assembly established in 1947. He also served as a member of the three-man Commission tasked with the critical responsibility of reorganisation of Indian States. Panikkar later served as Indian Ambassador China, Middle East, and France. He has written widely on Indian and Asian issues. See, for example, K.M. Panikkar, Common Sense about India, London: Victor Gollancz Ltd, 1960.

21.The Communist and Socialists were the left-leaning parties of the political divide. Although initially part of the Indian National Congress, they later parted ways to form their own parties and contested the first general elections of 1951-52. These parties perceived "Nehru was the agent of British capitalism and an instrument of imperial policy". Perceiving Indian independence was nominal, these parties thought it was their duty to "liberate" India, although this strategy was a failure. For this, see K.M. Panikkar, Common Sense about India, pp. 57-58.

22. Ibid., p.48.

23. Paul R. Brass, The New Cambridge History of India IV (1): The Politics of India Since Independence, pp. 94-95.

24. Bipan Chandra, Mridula Mukherjee and Aditya, India since Independence, Delhi: Penguin Books, 2000, p. 235.

25. Ibid.

26. W. H. Morris Jones, “The Indian Elections”, p. 114.

27 Election Commission India, Report on the First General Election in India Vol.1 General 1951-52, New Delhi: Manager Government of India Press, 1955, p. 95.

28. B.L. Sukhwal, Political Geography of India, New Delhi: Sterling Publishers, 1985, p. 110.

29. Bipan Chandra, Mridula Mukherjee and Aditya, India since Independence, p. 174.

30. Pran Chopra, Uncertain India: A Political Profile of two Decades of Freedom, London: Asia Publishing House, 1968, p.40.

31. Dilip Hiro, Inside India Today, London: Routledge and Kegan Paul, 1976, p. 73.

32. Ibid., p. 74; For further discussion on the adoption of socialist developmental model by the Indian National congress, see Bipan Chandra, Mridula Mukherjee and Aditya, India since Independence, pp. 249-251.

33. A. Krishnas wami, The Indian Union and the States: A Study in Autonomy and Integration, Oxford: Pergamon Press, 1964), p.37.

34. Colin Jackson, The New India, Fabian International Bureau, 1957, p.12.

35. Bipan Chandra, Mridula Mukherjee and Aditya, India since Independence, pp. $153 \& 160$.

36. A. Krishnaswami, The Indian union and the States: A study in Autonomy and Integration, Oxford: Pergamon Press, 1965, pp. 30-31 \& 53-55. See also V.D. Mahajan, A History of India Part III (Modern India), New Delhi: S. Chand \& Company, 1990, p. 368.

37. Bipan Chandra, Mridula Mukherjee and Aditya , India since Independence, pp. 153.

38. W.H. Morris-Jones, Language and Region within the Indian Union, pp. 62-63

39. Bipan Chandra, Mridula Mukherjee and Aditya, India since Independence, p. 128. See also, Norman D. Palmer, Elections and Political Development: The South Asian Experience, p. 109.

40. Norio Kondo, Indian Parliamentary Elections after Independence: Social Changes and Electoral Participation, Chiba: Institute of Developing Economies [IDE] JETRO, 2003, p.10. See also, W.H. Morris-Jones, Language and Region within the Indian Union, pp. 60-61. 